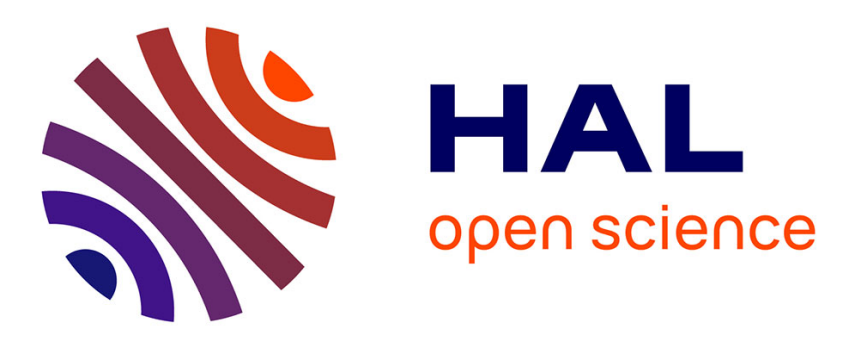

\title{
Assessment of the al corner of the ternary Al-Fe-Si system
}

Luiz Eleno, Josef Vezelý, Bo Sundman, Miroslav Cieslar, Jacques Lacaze

\section{To cite this version:}

Luiz Eleno, Josef Vezelý, Bo Sundman, Miroslav Cieslar, Jacques Lacaze. Assessment of the al corner of the ternary Al-Fe-Si system. Materials Science Forum, 2010, vol. 649, pp. 523-528. 10.4028/www.scientific.net/MSF.649.523 . hal-00863185

\section{HAL Id: hal-00863185 \\ https://hal.science/hal-00863185}

Submitted on 18 Sep 2013

HAL is a multi-disciplinary open access archive for the deposit and dissemination of scientific research documents, whether they are published or not. The documents may come from teaching and research institutions in France or abroad, or from public or private research centers.
L'archive ouverte pluridisciplinaire HAL, est destinée au dépôt et à la diffusion de documents scientifiques de niveau recherche, publiés ou non, émanant des établissements d'enseignement et de recherche français ou étrangers, des laboratoires publics ou privés. 


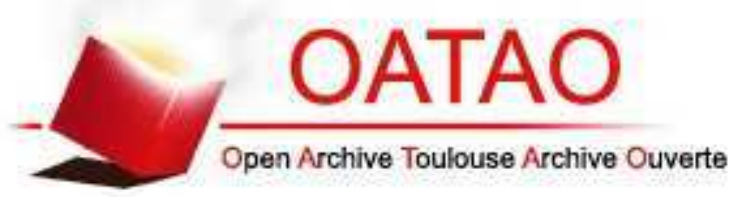

\section{Open Archive TOULOUSE Archive Ouverte (OATAO)}

OATAO is an open access repository that collects the work of Toulouse researchers and makes it freely available over the web where possible.

This is an author-deposited version published in : http://oatao.univ-toulouse.fr/ Eprints ID : 8683

To link to this article : DOI:10.4028/www.scientific.net/MSF.649.523

URL : http://dx.doi.org/10.4028/www.scientific.net/MSF.649.523

To cite this version : Eleno, Luiz and Vezelý, Josef and Sundman, Bo and Cieslar, Miroslav and Lacaze, Jacques. Assessment of the al corner of the ternary Al-Fe-Si system. (2010) Materials Science Forum, vol. 649 . pp. 523-528. ISSN 1662-9752

Any correspondance concerning this service should be sent to the repository administrator: staff-oatao@ listes-diff.inp-toulouse.fr 


\title{
Assessment of the Al corner of the ternary Al-Fe-Si system
}

\author{
Luiz Eleno, ,a Josef Vezelý, 2,b Bo Sundman,, ${ }^{1, c}$ Miroslav Cieslar, ${ }^{2, d}$ \\ Jacques Lacaze ${ }^{1, \mathrm{e}}$ \\ ${ }^{1}$ CIRIMAT, UMR CNRS/UPS/INPT, ENSIACET, 31077 Toulouse cedex 4, France \\ ${ }^{2}$ Charles' University in Prague, Faculty of Mathematics and Physics, Ke Karlovu 5, 12116 Prague \\ 2, Czech Republic \\ a'Luiz.Eleno@ensiacet.fr, 'Bo.Sundman@ensiacet.fr, 'Jacques.Lacaze@ensiacet.fr, \\ bvesej3am@mail.kolej.mff.cuni.cz, ${ }^{\mathrm{d}}$ Miroslav.Cieslar@mff.cuni.cz
}

\section{Keywords: Thermodynamics, Al-Fe-Si, Phase diagram, Modelling, Assessment}

\begin{abstract}
The present work provides a review of the information available on the Al-rich corner of the $\mathrm{Al}-\mathrm{Fe}-\mathrm{Si}$ system as well as a CALPHAD type assessment making use of the COST 507 database as a starting point. The description of the intermetallic compounds has been modified to account for substitution of $\mathrm{Al}$ and $\mathrm{Si}$ in the ternary Al-Fe-Si system and to take new experimental information into account.
\end{abstract}

\section{Introduction}

Cast Al-Si aluminium alloys always contain additional species, either added intentionally or present as impurities, the control of which being more and more important as the use of scrap material increases. As a rule of thumb, manganese is added to Al-Si alloys containing iron in order to avoid precipitation of the so-called $\beta\left(\tau_{6}\right)$-AlFeSi phase that forms as elongated plates, thus decreasing the mechanical properties of the cast parts. This rule has been applied since long for improving the quality of cast parts but should be mastered through an appropriate description of phase equilibria in the $\mathrm{Al}-\mathrm{Fe}-\mathrm{Mn}-\mathrm{Si}$ system. In order to improve the thermodynamic description of the quaternary, it is necessary to reassess the description of the ternary systems as given in the COST 507 database [1], particularly the Al-Fe-Si system.

\section{Experimental information and previous assessments}

The complete ternary Al-Fe-Si system has been re-evaluated recently [2, 3] but the Al-rich corner still shows some controversies amongst the available experimental information. Most of the features of the Al-Fe-Si system were described in the extensive work of Takeda and Mutuzaki [4], who investigated the complete composition range. Earlier works are mentioned in reviews of the system [5-7]. Using the COST 507 as a starting point, Liu and Chang [8] evaluated the whole composition range in a thermodynamic assessment. Since then, further experimental work [2,9-13] has become available, which motivates a new assessment of the system. The new experimental data consist basically of formation enthalpy measurements $[12,13]$ and a reevaluation of the liquidus projection [9-11], which updates and corrects previous evaluations [e.g., 14]

The most recent assessment for the whole composition range has been done by $\mathrm{Du}$ et al. [3] for the complete system, but treating the Al-rich ternary phases as stoichiometric compounds and with some discrepancies with experiments in the Al-rich corner, mainly with regard to the extension of the primary solidification range of the $\beta\left(\tau_{6}\right)$ phase.

\section{Thermodynamic modelling}

To remain compatible with COST database only thermodynamic descriptions of the $\alpha\left(\tau_{5}\right), \beta\left(\tau_{6}\right)$, $\gamma\left(\tau_{2}\right)$, and $\delta\left(\tau_{4}\right)$ phases were altered. Table 1 summarises the sublattice models of these phases used in the present assessment. 
Table 1: Modelled ternary phases with references to crystal structure reports.

\begin{tabular}{lcl}
\hline Phase & Model Structure & ref. \\
$\alpha\left(\tau_{5}\right)$ & $\mathrm{Al}_{0.6612} \mathrm{Fe}_{0.19} \mathrm{Si}_{0.0496}(\mathrm{Al}, \mathrm{Si})_{0.0992}$ & {$[15]$} \\
$\beta\left(\tau_{6}\right)$ & $\mathrm{Al}_{0.598} \mathrm{Fe}_{0.152} \mathrm{Si}_{0.10}(\mathrm{Al}, \mathrm{Si})_{0.15}$ & {$[16,17]$} \\
$\gamma\left(\tau_{2}\right)$ & $\mathrm{Al}_{0.5} \mathrm{Fe}_{0.2} \mathrm{Si}_{0.1}(\mathrm{Al}, \mathrm{Si})_{0.2}$ & {$[18]$} \\
$\delta\left(\tau_{4}\right)$ & $\mathrm{Al}_{0.4166} \mathrm{Fe}_{0.1667} \mathrm{Si}_{0.25}(\mathrm{Al}, \mathrm{Si})_{0.1667}$ & {$[19]$} \\
\hline
\end{tabular}

The model for the $\alpha\left(\tau_{5}\right)$ phase was kept the same as in the COST database, since it already considered composition range as a line compound. For the $\beta\left(\tau_{6}\right)$ phase, the model from Liu and Chang [8] was employed. The composition ranges for both phases match well the experimental evidence.

Sublattices which would allow mixing between Al and Si were added to the models of $\gamma\left(\tau_{2}\right)$ and $\delta\left(\tau_{4}\right)$ phases. The crystal structure of the $\delta\left(\tau_{4}\right)$ phase is known [19], however X-ray diffraction can not distinguish neighbouring elements $\mathrm{Al}$ and Si. Munson [18] give either a monoclinic or cubic structure for $\gamma\left(\tau_{2}\right)$, while Pontevichi et al. [9] reports only a powder diffraction file. Coefficients of mixing sublattices for these compounds were therefore not based on crystal structures, but rather chosen to match observed composition ranges.

For all four compounds only linear temperature dependence of the excess parameters of the endmembers was considered. The ideal solution model was used for the four line compounds. The models for all other phases were kept the same as in the COST 507 database, apart for the liquid phase, to which was added a ternary interaction parameter.

The PARROT module of the Thermocalc [20] software was used for the optimization of the model parameters. Firstly, the data from Pontevichi et al. [9] at $1000 \mathrm{~K}$ were fitted using only temperatureindependent constants as excess parameters of the end-members. Then, enthalpies of formation at $298 \mathrm{~K}[12,13,21]$ were used to recalculate the linear temperature dependence.

A further optimization step was the introduction of data at $570^{\circ} \mathrm{C}$ and $600^{\circ} \mathrm{C}$ [22]. Then, a ternary interaction parameter for the liquid was introduced, to take into account the invariant equilibria involving the liquid phase $[2,11]$, which corrects and improves previous results [5]. Krendelsberger et al. [2] provided the temperatures for the invariant reactions, while the compositions were taken from Pontevichi et al. [11]. Finally, data for the isopleth with $13.5 \mathrm{wt}$. \% Si [10] were also fitted. Since this is a section of technological importance, a slightly higher weight in the optimization was assigned to these last results.

After the optimization, the model parameters were rounded following the recommendations of Lukas et al. [23]. The final set of parameters is as follows:

$$
\begin{aligned}
& G_{A l: F e: S i: A l}^{\alpha\left(\tau_{5}\right)}-0.7604 G_{A l}^{f c c}-0.19 G_{F e}^{b c c}-0.0496 G_{S i}^{d i a}=-28100+9.1 T \\
& G_{A l: F e: S i: S i}^{\alpha\left(\tau_{5}\right)}-0.6612 G_{A l}^{f c c}-0.19 G_{F e}^{b c c}-0.1488 G_{S i}^{d i a}=-25310+5 T \\
& G_{A l: F e: S i: A l}^{\beta\left(\tau_{6}\right)}-0.748 G_{A l}^{f c c}-0.152 G_{F e}^{b c c}-0.10 G_{S i}^{d i a}=-26900+12 T \\
& G_{A l: F e: S i: S i}^{\beta\left(\tau_{6}\right)}-0.598 G_{A l}^{f c c}-0.152 G_{F e}^{b c c}-0.25 G_{S i}^{d i a}=-19800+3 T \\
& G_{A l: F e: S i: A l}^{\gamma\left(\tau_{2}\right)}-0.7 G_{A l}^{f c c}-0.2 G_{F e}^{b c c}-0.1 G_{S i}^{d i a}=-27300+6.8 T \\
& G_{A l: F e: S i: S i}^{\gamma\left(\tau_{2}\right)}-0.5 G_{A l}^{f c c}-0.2 G_{F e}^{b c c}-0.3 G_{S i}^{d i a}=-28700+8 T \\
& G_{A l i: F e: S i: A l}^{\delta\left(\tau_{4}\right)}-0.5833 G_{A l}^{f c c}-0.1667 G_{F e}^{b c c}-0.25 G_{S i}^{d i a}=-18100 \\
& G_{A l: F e: S i: S i}^{\delta\left(\tau_{4}\right)}-0.4166 G_{A l}^{f c c}-0.1667 G_{F e}^{b c c}-0.4167 G_{S i}^{d i a}=-24700+7 T
\end{aligned}
$$


$L_{A l, F e, S i}^{L i q}=-110000+100 T$

\section{Results and discussion}

A calculated isothermal section at $590^{\circ} \mathrm{C}$ is shown in Fig 1(a), together with experimental data from Stefániay et al. [22]. It is seen that we have a good agreement with the experimental points, even though they show a large scattering. On the other hand, the fitted tie-triangle (filled squares in Fig. $1(\mathrm{a})$ ) is broader in the calculated diagram. This fact is not contradicted by the experiments, precisely because of their scattering.

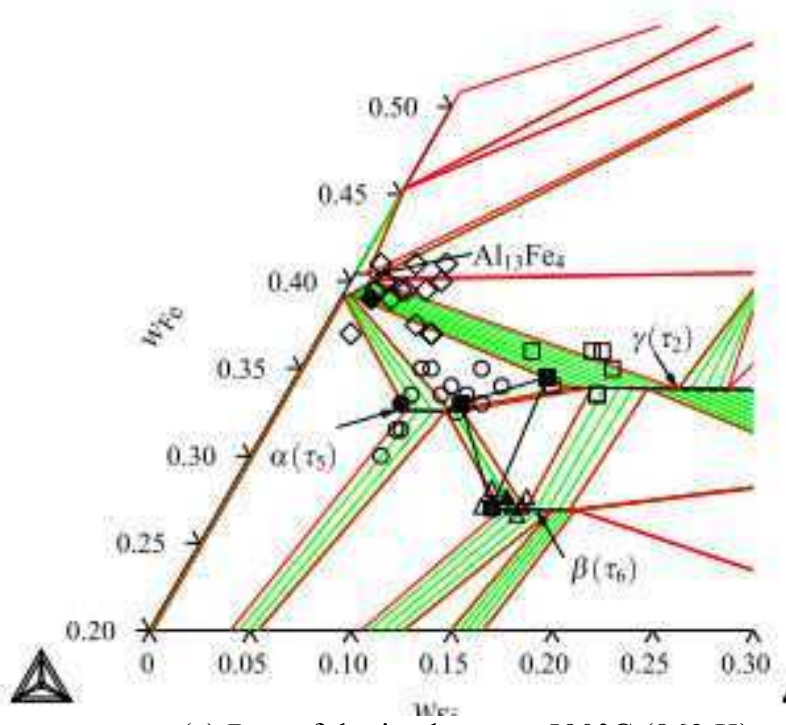

(a) Part of the isotherm at $590^{\circ} \mathrm{C}(863 \mathrm{~K})$.

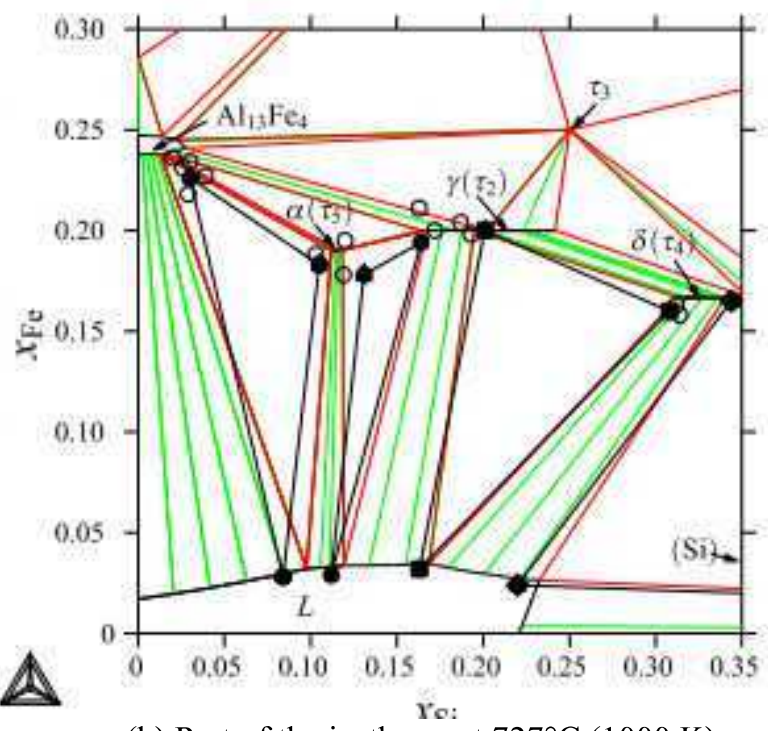

(b) Part of the isotherm at $727^{\circ} \mathrm{C}(1000 \mathrm{~K})$.

Fig. 1: Isotherms at (a) $590^{\circ} \mathrm{C}(863 \mathrm{~K})$ and (b) $727^{\circ} \mathrm{C}(1000 \mathrm{~K})$. The data from Stefániay et al. [22] at $570^{\circ} \mathrm{C}$ and $600^{\circ} \mathrm{C}$ was used in the fit at $590^{\circ} \mathrm{C}$, while the measurements of Pontevichi et al. [9] was used in the optimization at $727^{\circ} \mathrm{C}$. (Filled symbols denote data used in the optimization.)

Fig. 1(b) shows an isothermal section at $727^{\circ} \mathrm{C}(1000 \mathrm{~K})$, compared with data from Pontevichi et al. [9]. The calculation shows a slightly higher Fe content in the $\alpha\left(\tau_{5}\right)$ phase, which cannot be varied without changing the model of the phase, since it does not allow substitution of Fe. The agreement for the other tie-triangles is quite acceptable.

Table 2 compares the calculated and the experimental values $[2,11]$ of the invariant equilibria in the Al-rich corner of the ternary system. It is seen that the agreement is excellent. On the other hand, the calculated compositions for the invariant reactions, as seen from Fig. 2 is good for all reactions, except for $\mathrm{P}_{1}$ and $\mathrm{U} 4$, both involving the $\alpha\left(\tau_{5}\right)$ and the $\mathrm{Al}_{13} \mathrm{Fe}_{4}$ phases. The data of Takeda and Mutuzaki [4], Munson [18], and Zakharov et al. [24] (see Fig. 2) for these phases show a good agreement with our calculations, even thought they disagree strongly with respect to the range of $\beta\left(\tau_{6}\right)$ primary solidification. On the other hand, a higher weight has been assigned to the data from Pontevichi et al. [11], which justifies the above mentioned disagreement. The filled triangle in Fig 2 is an averaged composition for the $P_{1}$ reaction, used only for the sake of the optimization. It is not given by Pontevichi et al. [11], but it's temperature was determined by Krendelsberger et al. [2].

The isopleth section corresponding to $13.5 \mathrm{wt}$ \% $\mathrm{Si}$ is shown in Fig 3(a). There is an excellent agreement between the calculated liquidus line and the experimental values. As a further check, the isopleth with $5 \mathrm{wt}$ \% Fe is shown in Fig. 3(b), with experimental data from Takeda and Mutuzaki [4], and Zakharov et al. [24] (not used in the optimization), showing again an overall good agreement. 
Table 2: Calculated (present work) and measured $[2,11]$ invariant reaction temperatures in the Alrich corner of the Al-Fe-Si system.

\begin{tabular}{lllll}
\hline & Invariant Equilibrium & \multicolumn{3}{c}{ Temperature $\left({ }^{\circ} \mathrm{C}\right)$} \\
& & Ref. 2 & Ref. 11 & Calculated \\
\hline $\mathrm{P}_{1}$ & $L+A l_{13} F e_{4}+\gamma\left(\tau_{2}\right) \leftrightarrow \alpha\left(\tau_{5}\right)$ & 766 & & 757 \\
$\mathrm{P}_{2}$ & $L+\gamma\left(\tau_{2}\right)+\delta\left(\tau_{4}\right) \leftrightarrow \beta\left(\tau_{6}\right)$ & 665 & 667 & 669.7 \\
$\mathrm{U}_{3}$ & $L+\gamma\left(\tau_{2}\right) \leftrightarrow \alpha\left(\tau_{5}\right)+\beta\left(\tau_{6}\right)$ & 648 & 661 & 647.5 \\
$\mathrm{U}_{4}$ & $L+A l_{13} F e_{4} \leftrightarrow(A l)+\alpha\left(\tau_{5}\right)$ & 636 & 630 & 634 \\
$\mathrm{U}_{5}$ & $L+\alpha\left(\tau_{5}\right) \leftrightarrow(A l)+\beta\left(\tau_{6}\right)$ & 609 & 613 & 614.4 \\
$\mathrm{U}_{6}$ & $L+\delta\left(\tau_{4}\right) \leftrightarrow \beta\left(\tau_{6}\right)+(S i)$ & 596 & 596 & 597 \\
$\mathrm{E}_{7}$ & $L \leftrightarrow(A l)+(S i)+\beta\left(\tau_{6}\right)$ & 577 & 576 & 576 \\
\hline
\end{tabular}

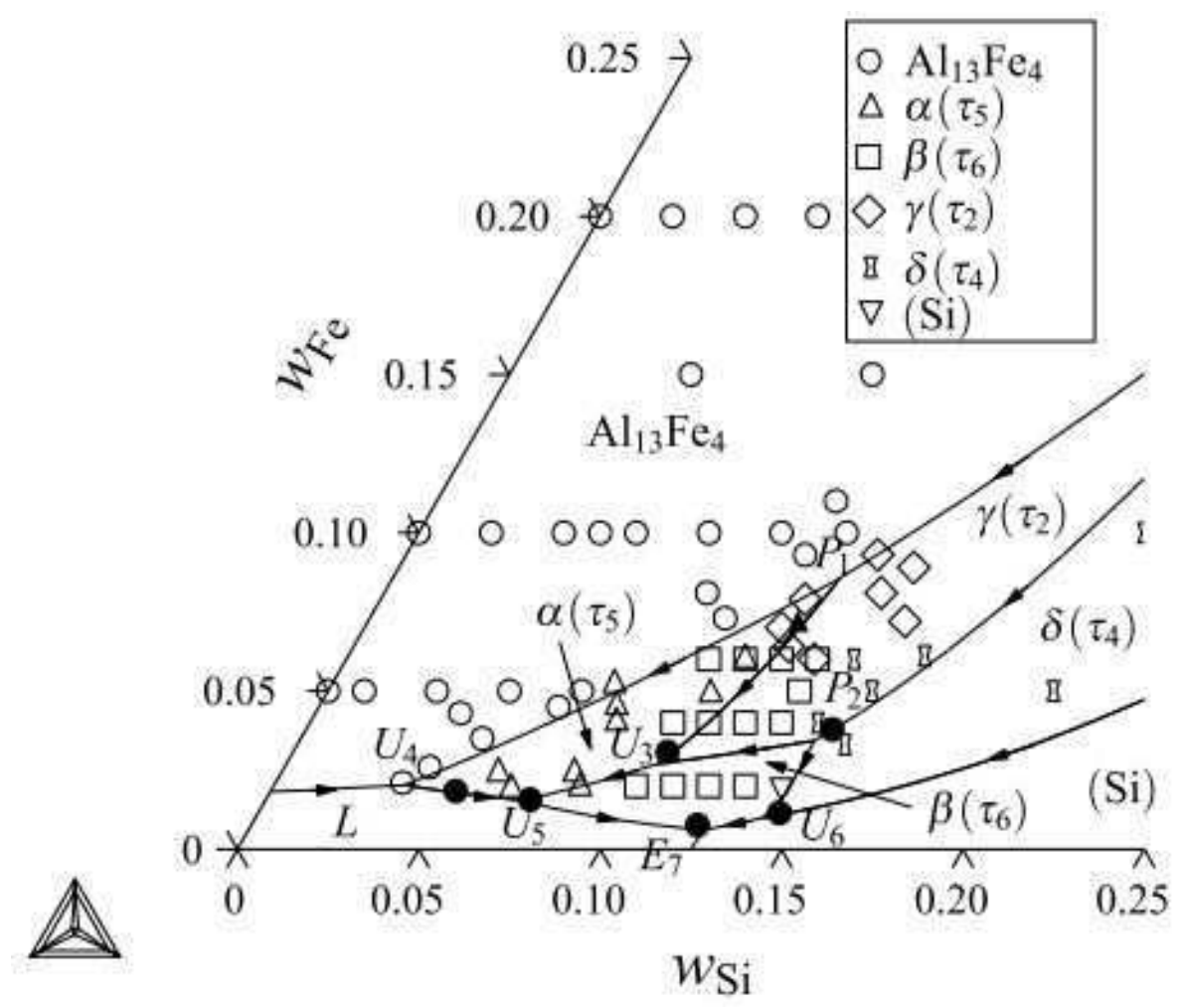

Fig. 2: Projection of the liquid troughs close to the Al-rich corner. The invariant points used in the fit $(\bullet)$ are from Pontevichi et al. [11] (compositions) and Krendelsberger et al. [2] (temperatures, not shown in the figure). The remaining data come from Takeda and Mutuzaki [4], Munson [18], and Zakharov et al. [24]. For the invariant reaction temperatures, see Table 2. The filled triangle is an averaged point for the $\mathrm{P}_{1}$ reaction, used only for the sake of the optimization. 


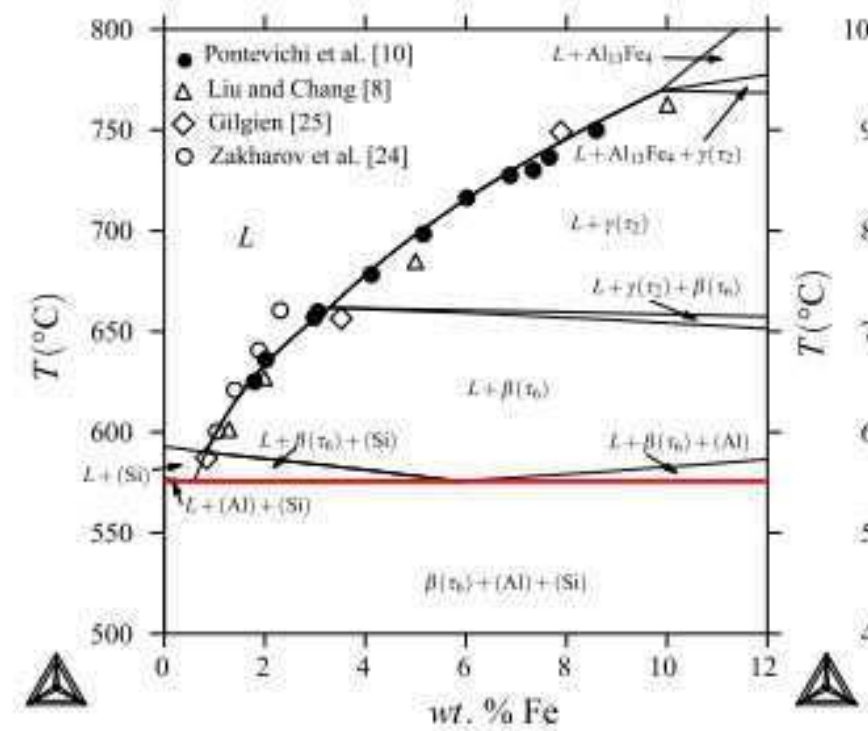

(a) Vertical section with 13.5 wt. \% Si.

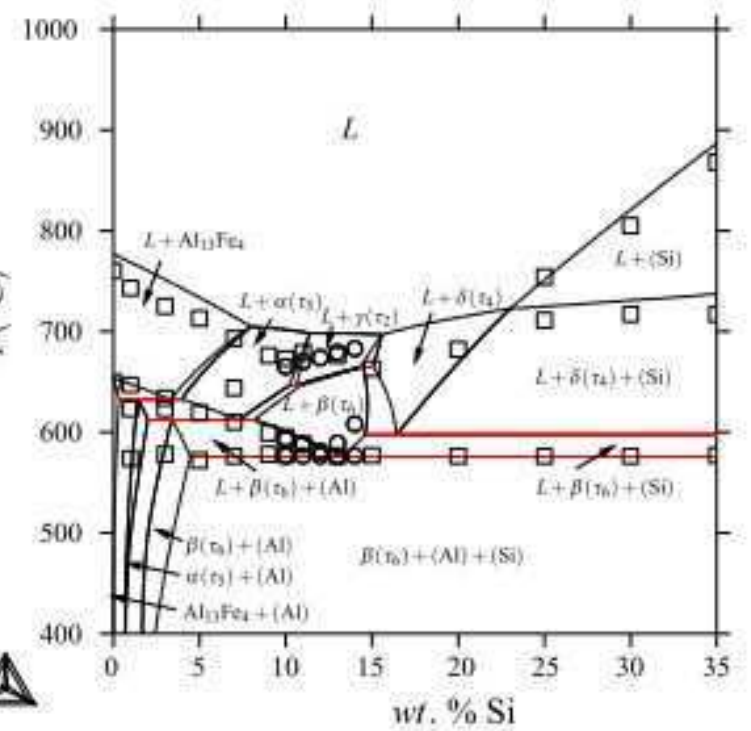

(b) Vertical section with 5 wt. \% Fe.

Fig. 3: (a) Isopleth with 13.5 wt. \% Si. The data used in the fit are those from Pontevichi et al. [10]. (b) Isopleth with 5 wt. \% Fe, with data from Takeda and Mutuzaki [4] (5 wt. \% Fe, $\square$ ) and Zakharov et al. [24] ( $\approx 6 \mathrm{wt} . \% \mathrm{Fe}, \circ)$. None of the data in Fig. 3(b) were used in the optimization.

\section{Conclusion}

The Al-rich corner of the Al-Fe-Si ternary system was reassessed in order to take new experimental evidence into account. The starting point for the thermodynamic optimization was the COST 507 database, allowing for substitution of $\mathrm{Al}$ and $\mathrm{Si}$ in the $\beta\left(\tau_{6}\right), \gamma\left(\tau_{2}\right)$ and $\delta\left(\tau_{4}\right)$ phases. That transformed the models of these phases into line compounds. The results show a good agreement with the available literature.

\section{Acknowledgements}

CNRS through a senior research grant (BS) as well as ESA (MICAST MAP project) are greatly acknowledged for their financial support of this research.

\section{References}

[1] I. Ansara, A. T. Dinsdale and M. H. Rand (eds.): COST 507 - Thermochemical database for light metal alloys, Vol. 2 (European Comission, Brussels 1998).

[2] N. Krendelsberger, F. Weitzer and J. C. Schuster: Metall. Mat. Trans. A Vol. 38 (2007), p. 1681.

[3] Y. Du, J. C. Schuster, Z.-K. Liu, R. Hu, P. Nash, W. Sun, W. Zhang, J. Wang, L. Zhang, C. Tang, Z. Zhu, S. Liu, Y. Ouyang, W. Zhang and N. Krendelsberger: Intermetallics Vol. 16 (2008), p. 554.

[4] S. Takeda and K. Mutuzaki: Tetsu to Hagane Vol. 26 (1940), p. 335.

[5] L. F. Mondolfo: Aluminum Alloys: Structure and Properties (Butter Worths, Boston, MA 1976).

[6] V. Rivlin and G. Raynor: Int. Metals Rev. Vol. 3 (1981), p. 133.

[7] G. Ghosh: COST 507 - Critical evaluation of ternary systems, Vol. 3 (European Comission, Brussels 1998), p. 113-175.

[8] Z.-K. Liu and A. Chang: Metall. Mat. Trans. A Vol. 30 (1999), p. 1081. 
[9] S. Pontevichi, F. Bosselet, F. Barbeau, M. Peronnet and J. C. Viala: J. Phase Eq. Diffus. Vol. 25 (2004), p. 528.

[10] S. Pontevichi, F. Bosselet, O. Dezellus, M. Peronnet, D. Rouby and J. C. Viala: J Phys. IV France Vol. 122 (2004), p. 75.

[11] S. Pontevichi, F. Bosselet, M. Peronnet and J. C. Viala: J. Phys. IV France Vol. 113 (2004), p. 81.

[12] Y. Li and B. Legendre: J. Alloys Compd. Vol. 302 (2000), p. 187.

[13] Y. Li, P. Ochin, A. Quivy, P. Telolahy and B. Legendre: J. Alloys Compd. Vol. 298 (2000), p. 198.

[14] H. W. L. Phillips and P. C. Varley: J. Inst. Metals Vol. 69 (1943), p. 317.

[15] R. N. Corby and P. J. Black: Acta Cryst. Vol. B 33 (1977), p. 3468.

[16] V. Hansen, B. Hauback, M. Sundberg, C. Røming and J. Gjønnes: Acta Cryst. Vol. B 54 (1998), p. 351.

[17] C. Røming, V. Hansen and J. Gjønnes: Acta Cryst. Vol. B 50 (1994), p. 307.

[18] D. Munson: J. Inst. Metals Vol. 95 (1967), p. 217.

[19] C. Gueneau, C. Servant, F. d'Yvoire and N. Rodier: Acta Cryst. Vol. C51 (1995), p. 177.

[20] J.-O. Andersson, T. Helander, L. Hoglund, P. Shi and B. Sundman: Calphad Vol. 26 (2002), p. 273.

[21] M. Vybornov, P. Rogl and F. Sommer: J. Alloys Compd. Vol. 247 (1997), p. 154.

[22] V. Stefániay, Á. Griger and T. Turmezey: J. Mat. Sci. Vol. 22 (1987), p. 539.

[23] H. L. Lukas, S. G. Fries and B. Sundman: Computational Thermodynamics: The Calphad Method (Cambridge University Press, Cambridge, UK 2007).

[24] A. M. Zakharov, I. T. Gul'din, A. A. Arnol'd and Y. A. Matsenko: Russ. Metall. Vol. 3 (1988), p. 177.

[25] P. Gilgien: Ph.D. thesis, EPFL, Lausanne (1996). 